\title{
Immunoglobulin Levels in the Cerebrospinal Fluid
}

\author{
D. RIDDOCH, ${ }^{*}$ M.B., M.R.C.P. ; R. A. THOMPSON, $\dagger$ M.B., B.SC., M.R.C.P.
}

\begin{abstract}
Cummary: The immunoglobulins $G, A, M$, and $D$ have been measured in the cerebrospinal fluid of 207 patients with neurological disease. Raised levels of IgG, expressed as a percentage of total cerebrospinal fluid (C.S.F.) protein, were found in $62 \%$ of 45 cases of multiple sclerosis compared with $14 \%$ of 160 cases with various other neurological disorders. Thus measurement of the IgG level is probably a useful confirmatory investigation in multiple sclerosis. IgA and IgM were found only in the C.S.F. of patients with a raised protein level, and IgD was not detected.
\end{abstract}

\section{Introduction}

Examination of the cerebrospinal fluid obtained by lumbar puncture has been a valuable aid to neurological diagnosis since its introduction over 70 years ago. More recently, electrophoretic methods have added to our knowledge of the individual protein fractions in health and disease; their disadvantage lies in the need for large quantities of fluid which require preliminary concentration, with possible resulting loss of protein and alteration in its physicochemical properties. Immunochemical methods are specific for a single protein and can be made sensitive enough to allow use of small amounts of unconcentrated cerebrospinal fluid (C.S.F.). The single radial diffusion method has been used to study the four main human immunoglobulins-IgG, IgA, IgM, and IgD-in the C.S.F. of patients with neurological disorders.

\section{Methods}

C.S.F. specimens were obtained from 207 unselected patients with a variety of definite or suspected neurological disorders-204 were lumbar fluids, 2 were ventricular, and 1 was cisternal. They were examined without concentration after the exclusion of macroscopically blood-stained specimens.

The immunoglobulin content was estimated by the single radial diffusion method of Fahey and McKelvey (1965), using specific antisera to human IgG, IgA, IgM, and IgD, prepared in sheep, according to the method described by Rowe et al. (1968). The standard for the IgG was a preparation of ether fractionated human IgG (Kekwick and Mackay, 1954), obtained from the Lister Institute, Herts., England. The standard for IgA and IgM was the serum of a healthy individual containing a known concentration of these immunoglobulins. The standard for $\operatorname{IgD}$ was the serum of another healthy individual with a high level of this protein. The lower limit of the sensitivity of the method was $1 \mathrm{mg} . / 100 \mathrm{ml}$. for IgG and IgD, $3 \mathrm{mg} . / 100 \mathrm{ml}$. for $\mathrm{IgA}$, and $1.5 \mathrm{mg} . / 100 \mathrm{ml}$. for IgM.

The total protein in the C.S.F. was estimated by the method

* Senior Registrar in Neurology, Queen Elizabeth Hospital, Birmingham

† Lecturer in Experimental Pathology, the University, Birmingham 15. of Folin (Lowry et al., 1951), on an AutoAnalyzer (Technicon Ltd.), with a known concentration of bovine serum albumin (Armour Laboratories Ltd.) as standard. The levels varied between 16 and $800 \mathrm{mg} . / 100 \mathrm{ml}$. In four cases where the protein level was very high insufficient C.S.F. was available for this method of estimation. Accordingly, in these cases only, the results obtained independently in the hospital biochemistry laboratory by the sulphosalicylic turbidimetric technique were accepted.

Immunoelectrophoresis of concentrated C.S.F. was carried out against antihuman IgG by the method of Grabar and Williams (1953) in $1.5 \%$ Noble agar (Difco) on the first 50 cases studied.

\section{Results}

IgD was never detected in the C.S.F. even in those with moderate serum levels of this immunoglobulin.

IgM was found in only four patients, all of whom had a total C.S.F. protein exceeding $150 \mathrm{mg} . / 100 \mathrm{ml}$; the highest concentration was $7 \mathrm{mg} . / 100 \mathrm{ml}$. in a patient with a total protein of $800 \mathrm{mg} . / 100 \mathrm{ml}$. Nevertheless, the C.S.F. of five other cases (including one of IgG myeloma) with protein values in excess of $150 \mathrm{mg} . / 100 \mathrm{ml}$. did not contain detectable IgM. It was concluded from the clinical protocol of these nine cases that the presence or absence of IgM had no diagnostic significance.

IgG Expressed as a Percentage of the Total C.S.F. Protein in 207 Cases According to Diagnosis

\begin{tabular}{|c|c|c|c|c|}
\hline \multirow{2}{*}{$\begin{array}{c}\text { No. } \\
\text { of } \\
\text { Cases }\end{array}$} & \multirow{2}{*}{\multicolumn{2}{|c|}{ Diagnosis }} & $\mathrm{IgG}$ as $\%$ of & Total Protein \\
\hline & & & Mean & Range \\
\hline $\begin{array}{r}45 \\
14 \\
14 \\
10 \\
9 \\
9 \\
8 \\
6 \\
3 \\
3 \\
5 \\
5 \\
4 \\
4 \\
7 \\
9 \\
2 \\
6 \\
29 \\
15\end{array}$ & 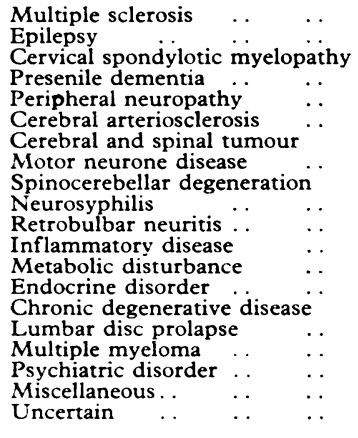 & 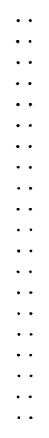 & $\begin{aligned} 18 \cdot 9 \\
7 \cdot 4 \\
7 \cdot 5 \\
11 \cdot 4 \\
10 \cdot 6 \\
6 \cdot 8 \\
11 \cdot 3 \\
9 \cdot 0 \\
5 \cdot 4 \\
13 \cdot 1 \\
12 \cdot 2 \\
10 \cdot 3 \\
6 \cdot 1 \\
8 \cdot 4 \\
10 \cdot 3 \\
8 \cdot 6 \\
64 \cdot 1 \\
8 \cdot 1 \\
8 \cdot 1 \\
10 \cdot 7\end{aligned}$ & 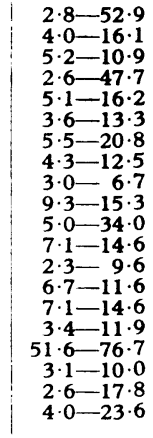 \\
\hline
\end{tabular}

IgA was found in 33 cases $(16 \%)$. This immunoglobulin was found only in C.S.F. specimens where the total protein was $\mathbf{4 0}$ mg. $/ 100 \mathrm{ml}$. or above. IgA was present in concentrations up to $42 \mathrm{mg} . / 100 \mathrm{ml}$. and constituted $1.5-14 \%$ of the total protein. High protein values increased the likelihood of $\operatorname{IgA}$ being detected (Fig. 1). It was found in seven out of nine cases of 
peripheral neuropathy in which the total protein ranged from 44 to $800 \mathrm{mg} . / 100 \mathrm{ml}$. It was detected in only 5 out of 45 cases of multiple sclerosis. Its presence or absence had no additional diagnostic value.

IgG was found in all the 207 specimens of cerebrospinal fluid examined (see Table). Its concentration varied considerably but, as can be seen in Fig. 2, 80\% of cases had a level of less than $8 \mathrm{mg} . / 100 \mathrm{ml}$. Two instances of high values (48 and $230 \mathrm{mg} . / 100 \mathrm{ml}$.) were found in patients with IgG myeloma, that a large number of the 45 clinically definite cases of multiple sclerosis had a raised IgG content. Raised levels were found in $28(62 \%)$ as opposed to $23(14 \%)$ of 160 cases with various other neurological diseases (Fig. 5). The mean percentage level of IgG in multiple sclerosis was 18.9 (S.D. 10.7) as opposed to 9.0 (S.D. 5.2) for the remainder. Further analysis of the multiple sclerosis cases showed no correlation between the IgG level and the age or sex of patient, length of history, or severity of disease. Cases were divided into active (clear-cut

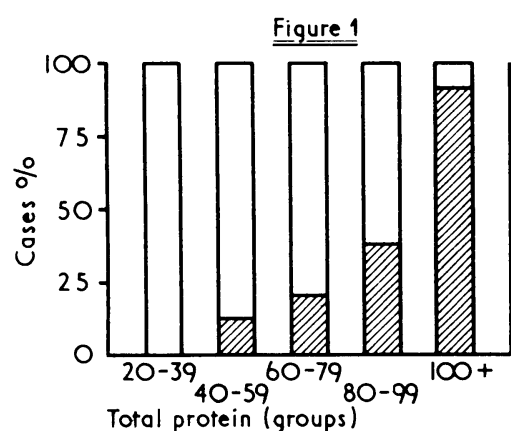

FIG. 1.-Percentage of cases containing IgA in the C.S.F., in relation to total protein. Shaded area indicates IgA present

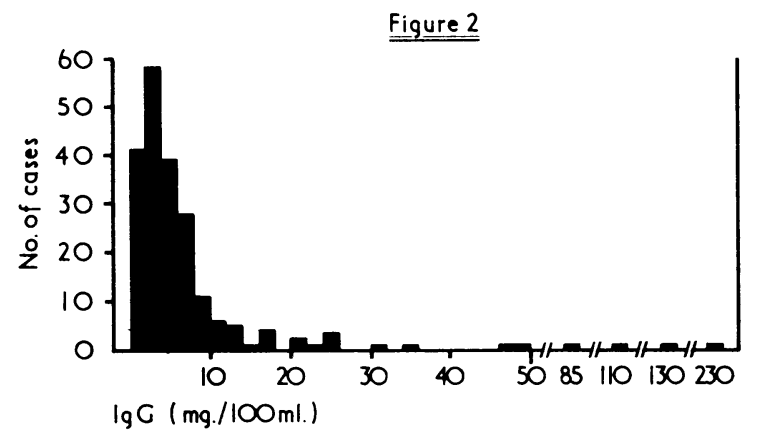

FIG. 2.-C.S.F. IgG levels in all 207 cases.

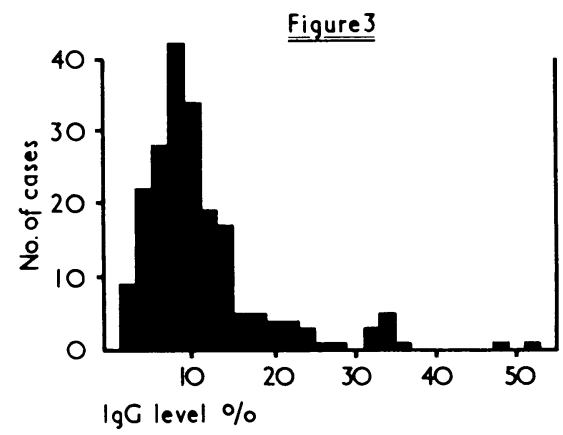

FIG. 3.-C.S.F. IgG levels in 205 cases (multiple myeloma), expressed as a percentage of the total C.S.F. protein. and these were rejected from further study. In the remaining 205 cases it was clear that the absolute level of IgG present in the C.S.F. was related to the total protein, and so the results were expressed as a percentage of the protein estimated by the Folin method (Fig. 3). Subsequently in this paper the IgG level will continue to be expressed in this way. As the series did not contain any normal controls we have taken as our upper limit of normal the figure of $13 \%$ obtained by Yahr et al. (1954), who used an immunochemical method.

Within this somewhat arbitrary level it can be seen (Fig. 4)
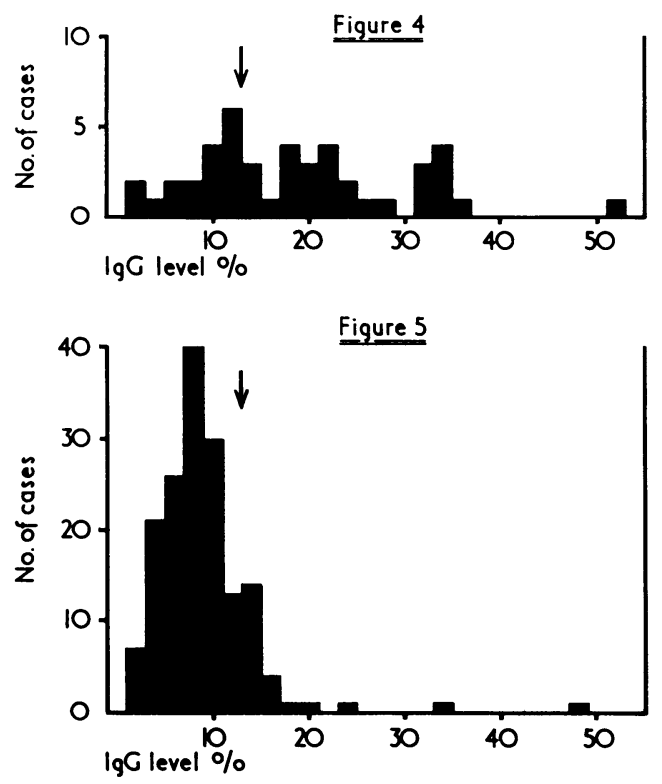

Fig. 4.-Percentage C.S.F. IgG levels in 45 cases of multiple sclerosis. Arrow indicates upper limit of normal.

FIG. 5.-Percentage C.S.F. IgG levels in 160 cases with miscellaneous neurological disorders. relapse within the previous three months) and quiescent, without there being any significant difference in IgG level between the groups. Some correlation was, however, established between the C.S.F. IgG level and the presence of an abnormal Lange test. Colloidal gold curves were carried out in 38 of the 45 cases of multiple sclerosis. Eight showed first zone changes, and all of these had raised IgG levels, with a mean of $27.3 \%$ (S.D. 6.2). In contrast the remaining 30 cases with negative Lange curves had a mean of $16.5 \%$ (S.D. 9.2), and 16 of these exceeded the normal IgG level. The difference is significant (difference of means $=3.9$ times the standard error). As only three cases of multiple sclerosis were found to have a pleocytosis in the C.S.F. it was not possible to analyse this aspect in relation to IgG content.

Of the 45 cases only one had a total protein greater than $100 \mathrm{mg} . / 100 \mathrm{ml}$., 29 cases had less than $50 \mathrm{mg} . / 100 \mathrm{ml}$., and 15 were in the range $50-100 \mathrm{mg} . / 100 \mathrm{ml}$. The mean percentage IgG level in each of these two groups was very similar (18.8 and 19.2 respectively). Thus it appeared that in the multiple sclerosis cases a raised C.S.F. protein had little or no effect on the percentage IgG level.

The electrophoretic mobility of gammaglobulin in the C.S.F. of multiple sclerosis cases has been studied by various authors. While some (Kutt et al., 1960; Dencker and Swahn, 1961; Clausen et al., 1964) found the main increase in the slowly migrating cathodic fraction, others (Lowenthal et al., 1960; Lamoureux and Borduas, 1966) noted denser anodic precipitation. In view of these conflicting findings, the first 50 C.S.F. specimens were concentrated 5 to 10 times by ultrafiltration and subjected to immunoelectrophoresis in agar against antihuman IgG. Among these were several cases of multiple sclerosis in which the IgG was always observed to migrate to a position compatible with normal serum IgG. One specimen from a patient not suffering from multiple sclerosis showed a doubtfully increased mobility of the IgG towards the anode.

Analysis of the 160 cases with miscellaneous neurological diagnoses was also carried out. It can be seen (Fig. 6) that raised percentage levels of IgG are more common in C.S.F.s with a high total protein content, and are present in 7 out of 12 cases where this exceeds $100 \mathrm{mg} . / 100 \mathrm{ml}$. The 23 cases 
with a raised percentage of IgG included three with suspected but not clinically definite multiple sclerosis. In most of the non-multiple sclerosis cases with a raised IgG level the rise was small. Only four of the miscellaneous 160 cases had figures above $20 \%$ as opposed to 19 of the 45 cases of multiple

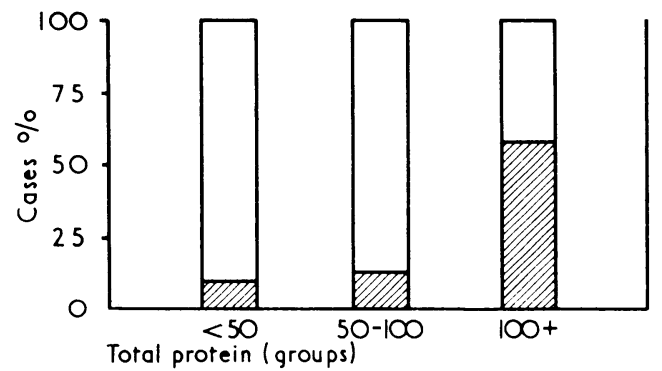

FIG. 6.-Percentage of non-multiple sclerosis cases showing a raised C.S.F. IgG level in relation

sclerosis. The diagnoses in these four cases were presenile dementia, bilateral retrobulbar neuritis (? demyelinating), cerebral metastases, and an undiagnosed neurological condition in a woman showing a raised serum IgG level. IgG levels in the non-multiple sclerosis group showed no correlation with age. A curious feature, however, emerged in that the values for 94 males (mean 10.1, S.D. 5.9) were significantly higher than those for 66 females (mean 7.6, S.D. 3.7) (difference of means $=3.3$ times the standard error). The reason for this is uncertain, as high total protein values did not predominate in the C.S.F. specimens from male cases.

Certain diagnostic groups were considered in greater detail. Cervical spondylosis (14 cases), motor neurone disease (6 cases), and spinocerebellar degeneration (3 cases), all of which may be confused clinically with multiple sclerosis, showed normal levels. Of nine cases of cerebral arteriosclerosis, a slightly raised IgG content $(13.3 \%)$ was found in only one. Of the three cases of neurosyphilis in this series, figures of 9.3 and $14.8 \%$ were present in two cases of burnt-out tabes and $15.3 \%$ in the ventricular fluid of a man with active meningovascular syphilis. Normal levels were found in two childhood cases of transverse myelitis, and in four out of five cases of retrobulbar neuritis. The fifth case, with a figure of $34 \%$, was a man of 26 in whom the diagnosis lay between demyelination of the optic nerves and Leber's disease. Out of nine cases of peripheral neuropathy IgG levels were raised in three, all of which had total C.S.F. proteins exceeding $200 \mathrm{mg} . / 100 \mathrm{ml}$. Two out of 10 cases of presenile dementia had raised levels (one very high at $47.7 \%$ ), and both of these had shown a rapidly progressive mental deterioration with extrapyramidal signs. By contrast, three patients with a biopsy-proved $\mathrm{Alz}$ heimer's disease all had IgG levels under $4 \%$.

\section{Discussion}

Interest in the protein fractions of C.S.F. was stimulated by the work of Kabat et al. (1942), who first applied Tiselius electrophoresis to this fluid, and found increased gammaglobulin levels in neurosyphilis, which were independent of serum changes. Similar abnormality was apparent in two cases of multiple sclerosis. Their findings have largely been confirmed by many authors who have used paper and gel electrophoresis (Cumings, 1953; Plum and Fog, 1959; Bronsky et al., 1960; Ivers et al., 1961; Schapira and Park, 1961; Johns- clottir and Lowenthal, 1962; Bergmann et al., 1964; Bradshaw, 1964; Clausen et al., 1964; Cosgrove and Agius, 1966), immunoelectrophoresis (Dechaume et al., 1962; Laterre et al., 1962; Dencker, 1964; Lamoureux and Borduas, 1966), chemical precipitation (Roboz et al., 1953; Volk et al., 1955; Ziegler and Ross, 1955; Hanok, 1961; Foster and Horn, 1962; Prineas et al., 1966), immunoprecipitation (Kabat et al., 1948), and electroimmunodiffusion (Schneck and Claman, 1969). The proportion of multiple sclerosis cases showing a raised gammaglobulin has varied between the $40 \%$ of Bradshaw (1964) and the $88 \%$ of Schapira and Park (1961). Two large series of patients with multiple sclerosis analysed by Tourtellotte (1963) and by Yahr et al. (1954) showed raised levels in 50\% of 387 cases and $66.5 \%$ of 244 cases respectively. The latter authors also found abnormal gammaglobulin levels in $74 \%$ of 35 cases of neurosyphilis.

The reason why only a proportion of multiple sclerosis cases show a raised gammaglobulin level in the C.S.F. remains obscure. Several workers have tried to correlate this feature with various aspects of the disease, including duration, severity, mode of onset, activity, number of relapses, site of lesion, and the C.S.F. cell count or its total protein (Kabat et al., 1950; Roboz et al., 1953; Yahr et al., 1954; Bronsky et al., 1960; Hanok, 1961; Ivers et al., 1961; Schapira and Park, 1961; Bergmann et al., 1964; Cosgrove and Agius, 1966; Lamoureux and Borduas, 1966; Prineas et al., 1966). The findings have varied from one group to another, with no clear picture emerging, and, as already mentioned, we have failed to find a correlation between clinical aspects of the disease and percentage IgG level. Nevertheless, most authors have found, as we have, a good correlation between gammaglobulin levels and paretic changes in the Lange curve. This is not surprising, as it is well established that gammaglobulin causes precipitation of colloidal gold, which can be inhibited by albumin (Gray, 1942; Kabat et al., 1942; Freedman and Merritt, 1950; Press, 1956). Several of our multiple sclerosis cases, however, had a negative Lange curve in the presence of a raised C.S.F. IgG. The site of production of the pathological globulin remains uncertain (Bing and Neel, 1942; Tourtellotte and Parker, 1966; Cohen and Bannister, 1967). The consensus of opinion (Field, 1954; Caspary, 1965; Lippincott et al., 1965) is that the abnormal globulin is formed locally, either in the neuraxis itself or from the white cells in the C.S.F., rather than diffusing from the plasma through a selectively permeable blood-brain barrier.

After excluding neurosyphilis and multiple sclerosis most authors have found a small percentage of cases with other neurological diseases which showed a raised gammaglobulin level, and we obtained a figure of $13 \%$ (21 out of 157), which falls to $10 \%$ when cases with a total protein of $100 \mathrm{mg} . / 100$ $\mathrm{ml}$. or less are considered. Raised levels have particularly been noted by other workers in subacute sclerosing panencephalitis (Dencker and Kolár, 1965) and also in postexanthematous and postvaccinial "allergic" encephalomyelitis. In the present series higher than usual levels of IgG were found in a variety of disorders. Nevertheless, those cases likely to be confused clinically with multiple sclerosis showed uniformly normal levels. The results in presenile dementia are interesting and may suggest a method of separating the different groups.

Our findings of IgA and IgM in cerebrospinal fluids with a raised total protein are in agreement with the work of Laterre et al. (1962) and Schneck and Claman (1969), who also found their presence to be of no diagnostic value. In normal people the globulins of higher molecular weight are absent from the C.S.F., or are present in only minute quantities (Dencker et al., 1961; Burtin, 1964; Matzke and Clausen, 1965; Ursing, 1965).

Though IgD was not detected in this series by the method used, Tavolato and De Zanche (1968), using immunoelectro- 
phoresis of concentrated C.S.F., found it in 19 out of 30 neurological cases. It was absent or scarcely apparent in 10 controls. Its presence was related to the total protein level.

That abnormalities of the serum protein fractions are reflected in the C.S.F. is well recognized. Our two cases of IgG myeloma had very high levels of this immunoglobulin in the cerebrospinal fluid: $76.7 \%$ (spinal block) and $51.6 \%$. In the former case immunoelectrophoresis showed that the myeloma protein was clearly the dominant protein present. Though Volk et al. (1955) recognized specific serum protein changes in multiple sclerosis, most authors have found no significant abnormality (Schapira and Park, 1961; Bradshaw, 1964). In the present series qualitative immunoglobulin estimations were carried out on the sera of 11 multiple sclerosis and 42 non-multiple sclerosis cases. Apart from the two examples of IgG myeloma, this immunoglobulin was raised in the serum of only one patient. All the multiple sclerosis cases showed normal levels.

\section{Conclusion}

The main interest of our findings has been in the immunoglobulin $G$ fraction and its value in the diagnosis of multiple sclerosis. Though a small proportion of other neurological disorders show a raised IgG in the C.S.F., the rise tends to be small, and is more common when the total protein exceeds $100 \mathrm{mg}$. $/ 100 \mathrm{ml}$. In multiple sclerosis this total protein value is reached in only some 3\% of patients (Locoge and Cumings, 1958). Thus the finding of a high percentage of IgG in the C.S.F. in the presence of a normal or moderately raised total protein must immediately suggest the diagnosis of multiple sclerosis in clinically doubtful cases.

We wish to express our gratitude to Professor J. Hardwicke, in whose department the total C.S.F. protein estimations were carried out by Miss V. Bayliss. Our thanks are also due to Dr. J. M. Jefferson and Dr. Michael Small, who gave valuable help and advice, in addition to providing most of the patients studied. Dr. J. A. H. Waterhouse kindly advised us on the statistical interpretation of the results.

\section{REFERENCES}

Bergmann, L., Gilland, O., Olanders, S., and Svennerholm, L. (1964). Acta Neurologica Scandinavica, 40, Suppl. No. 10, p. 33.

Bing, J., and Neel, A. V. (1942). Acta Medica Scandinavica, 111, 57

Bradshaw, P. (1964). Fournal of the Neurological Sciences, 1, 374.

Bronsky, D., Kaplitz, S. E., Muci, J., Dubin, A., and Chesrow, E. J. (1960). Fournal of Laboratory and Clinical Medicine, 56, 382.

Burtin, P. (1964). In Immuno-Electrophoretic Analysis, edited by P. Grabar and P. Burtin, p. 244. Amsterdam, Elsevier.

Caspary, E. A. (1965). fournal of Neurology, Neurosurgery and Psychiatry, 28, 61.

Clausen, J., Matzke, J., and Gerhardt, W. (1964). Acta Neurologica Scandinavica, 40, Suppl. No. 10, p. 49.

Cohen, S., and Bannister, R. (1967). Lancet, 1, 366.

Cosgrove, J. B. R., and Agius, P. (1966). Neurology (Minneapolis), 16, 197.
Cumings, J. N. (1953). Fournal of Neurology, Neurosurgery and Psychiatry, 16, 152.

Dechaume, J., Manuel, Y., Bourrat, C., Creyssel, R., and Robert, J. (1962). Fournal de Médecine de Lyon, 43, 589.

Dencker, S. J. (1964). Acta Neurologica Scandinavica, 40, Suppl. No. 10, p. 57.

Dencker, S. J., Brönnestam, R., and Swahn, B. (1961). Neurology (Minneapolis), 11, 441.

Dencker, S. J., and Koláł, O. (1965). Acta Neurologica Scandinavica, 41, Suppl. No. 13, p. 135.

Dencker, S. J., and Swahn, B. (1961). Lunds Universitets Arsskrift, 57, Suppl. No. 10.

Fahey, J. L., and McKelvey, E. M. (1965). Fournal of Immunology, 94, 84.

Field, E. O. (1954). fournal of Neurology, Neurosurgery and Psychiatry, 17, 228.

Foster, J. B., and Horn, D. B. (1962). British Medical fournal, 1, 1527.

Freedman, D. A., and Merritt, H. H. (1950). Research Publications of the Association for Research into Nervous and Mental Diseases, $28,428$.

Grabar. P.. and Williams, C. A. (1953). Biochimica et Biophysica Acta, 10, 193.

Gray, S. J. (1942). Proceedings of the Society for Experimental Biology and Medicine, 51, 401

Hanok, A. (1961). Fournal of Laboratory and Clinical Medicine, 57, 42. Ivers, R. R., McKenzie, B. F., McGuckin, W. F., and Goldstein, N. P. (1961). Foumal of the American Medical Association, 176, 515.

Johnsclottir, K., and Lowenthal, A. (1962). World Neurology, 3, 659.

Kabat, E. A., Freedman, D. A., Murray, J. P., and Knaub, V. (1950) American fournal of the Medical Sciences, 219, 55.

Kabat, E. A., Glusman, M., and Knaub, V. (1948). American fournal of Medicine, 4, 653.

Kabat, E. A., Moore, D. H., and Landow, H. (1942). Fournal of Clinical Investigation, 21, 571 .

Kekwick, R. A., and Mackay, M. E. (1954). Medical Research Council Special Report Series, No. 286. London: H.M.S.O

Kutt, H., McDowell, F., Chapman, L., Pert, J. H., and Hurwitz, L. J. (1960). Neurology '(Minneapolis), 10, 1064

Lamoureux, G., and Bordaus, A. G. (1966). Clinical and Experimental Immunology, 1, 363.

Laterre, E. C., Heremans, J.-F., and Demanet, G. (1962). Revue Neurologique, 107, 500.

Lippincott, S. W., Korman, S., Lax, L. C., and Corcoran, C. (1965). fournal of Nuclear Medicine, 6, 632.

Locoge, M., and Cumings, J. N. (1958). British Medical fournal, 1, 618. owenthal, A., van Sande, M., and Karcher, D. (1960). Journal of Neurochemistry, 6, 51 .

Lowry, O. H., Rosebrough, N. J., Farr, A. L., and Randall, R. J. (1951). fournal of Biological Chemistry, 193, 265.

Matzke, J., and Clausen, J. (1965). Acta Neurologica Scandinavica 41, Suppl. No. 13, p. 129.

Plum, C. M., and Fog, T. (1959). Acta Psychiatrica et Neurologica Scandinavica, 34, Suppl. No. 128.

Press, E. M. (1956). Biochemical fournal, 63, 367

Prineas, J., Teasdale, G., Latner, A. L., and Miller, H. (1966). British Medical fournal, 2, 922.

Roboz, E., Hess, W. C., and Forster, F. M. (1953). Neurology (Minneapolis), 3, 410.

Rowe, D. S., McGregor, I. A., Smith, S. J., Hall, P., and Williams, K. (1968). Clinical and Experimental Immunology, 3. 63.

Schapira, K., and Park, D. C. (1961). Fournal of Neurology, Neurosurgery and Psychiatry, 24, 121.

Schneck, S. A., and Claman, H. N. (1969). Archives of Neurology, 20, 132.

Tavolato, B., and De Zanche, L. (1968). Acta Neurologica Scandinavica, 44. 384.

Tourtellotte, W. W. (1963). Medical Clinics of North America, 47, 1619.

Tourtellotte, W. W., and Parker, J. A. (1966). Science, 154, 1044.

Ursing, B. (1965). Acta Medica Scandinavica, Suppl. No. 429.

Volk, B. W., Saifer, A., Rabiner, A. M., and Oreskes, I. (1955). Archives of Neurology and Psychiatry, 73, 66.

Yahr, M. D., Goldensohn, S. S., and Kabat, E. A. (1954). Annals of the New York Academy of Sciences, 58, 613.

Ziegler, D. K., and Ross, G. (1955). Neurology (Minneapolis), 5, 573. 